\title{
Holocene Bowhead Whale (Balaena mysticetus) Mortality Patterns in the Canadian Arctic Archipelago
}

\author{
JAMES M. SAVELLE, ${ }^{1}$ ARTHUR S. DYKE ${ }^{2}$ and ALLEN P. McCARTNEY ${ }^{3}$
}

(Received 13 April 1999; accepted in revised form 25 April 2000)

\begin{abstract}
Changes according to elevation in frequencies of naturally stranded bowhead whale (Balaena mysticetus) remains on Holocene beaches in the Canadian Arctic Archipelago (CAA) closely parallel previously reported temporal changes in frequencies of independently radiocarbon-dated bowhead remains from these same beaches. Specifically, on the basis of emergence curves determined for 10 localities surveyed in the CAA, stranded whale remains tend to be relatively common in beaches dating to approximately $2500-5500$ B.P. and those older than 8000 B.P., but relatively rare in beaches dating to $0-2500$ B.P. and 5500-8000 B.P. The former beaches apparently developed primarily during periods of relatively ice-free summer conditions, while the latter developed during periods of relatively pervasive summer sea ice that prevented bowheads from entering the region. Length-based mortality profiles of the stranded whale assemblages suggest that random processes, such as ice entrapment, were responsible for the death of most whales found on these beaches.
\end{abstract}

Key words: bowhead whale, climate change, Holocene, mortality profiles, sea ice

RÉSUMÉ. Des changements en fonction de l'altitude dans la fréquence de restes de baleines boréales (Balaena mysticetus) sur les plages de l'holocène situées dans l'archipel Arctique canadien (AAC) correspondent de près aux changements temporels rapportés précédemment dans la fréquence des restes de baleine boréale datés indépendamment au radiocarbone trouvés sur ces mêmes plages. Plus précisément, en se fondant sur les courbes d'émersion déterminées pour dix localités étudiées dans l'AAC, les restes de baleine échouées ont tendance à être assez communs sur les plages qui datent d'environ 2500 à 5500 BP et sur celles qui remontent à plus de $8000 \mathrm{BP}$, tandis qu'ils sont relativement rares sur les plages qui datent de 0 à $2500 \mathrm{BP}$ et de 5500 à 8000 BP. Les premières plages auraient été créées surtout durant des périodes où il n'y avait pratiquement pas de glace estivale, tandis que les dernières se seraient formées au cours de périodes où la glace d'été envahissante empêchait les baleines boréales de pénétrer dans cette zone. Les profils de mortalité des assemblages de baleines échouées, profils fondés sur la longueur, suggèrent que des processus aléatoires, tels que l'enfermement dans la glace, ont été responsables de la mort de la plupart des baleines trouvées sur ces plages.

Mots clés: baleine boréale, changement climatique, holocène, profils de mortalité, glace marine

Traduit pour la revue Arctic par Nésida Loyer.

\section{INTRODUCTION}

In a series of recent studies, Dyke and colleagues (Dyke and Morris, 1990; Dyke et al., 1991, 1996a, b, 1997; Tremblay et al., 1997) have demonstrated that century-tomillennial variations in the expansion and contraction of sea ice and changes in surface currents in the Arctic Ocean and Baffin Bay are important aspects of the environmental history of northern polar regions. Of the few proxy sources for the interpretation of sea ice history in the Canadian Arctic Archipelago (CAA), fossil bowhead whale remains on raised beach sequences are particularly useful, in part because the remains are regionally either abundant, rare, or absent in deposits of certain ages. A Holocene sea ice history has been proposed for the Canadian High Arctic on the basis of changes in the relative abundance of bowhead remains through time. The initial data used, from 53 radiocarbon-dated samples from the central CAA (Dyke and Morris, 1990), were later augmented to include over 400 such samples from widespread sites in the central and eastern CAA (Dyke et al., 1996b).

Dyke et al. (1996b) identified several periods of longterm summer sea ice expansion and contraction in the CAA, a brief summary of which follows. Deglaciation of the central archipelago occurred approximately $11000-$ 9000 years B.P., with bowheads immediately occupying deglaciated regions. By approximately $8500-8000$, a major change in sea ice conditions occurred: the bowhead summer range shrank to the easternmost inlets bordering northern Baffin Bay (e.g., Admiralty and Navy Board

\footnotetext{
${ }^{1}$ Department of Anthropology, McGill University, 855 Sherbrooke St. West, Montreal, Quebec H3A 2T7, Canada; savelle@leacock.lan.mcgill.ca

${ }^{2}$ Terrain Sciences Division, Geological Survey of Canada, 601 Booth St., Ottawa, Ontario K1A 0E8, Canada

${ }^{3}$ Department of Anthropology, University of Arkansas, Fayetteville, Arkansas 72701, U.S.A.

(C) The Arctic Institute of North America
} 
Inlets), and sea ice blocked the remaining areas from Prince Regent Inlet westward. These conditions continued until approximately 5500 to 5000 B.P., at which time the bowhead range increased, exceeding the recorded historic range. Between 3000 and 2000 B.P., the range was again reduced to resemble the historic range. Although the range apparently expanded slightly at approximately 1000 B.P., this occurred during an otherwise overall reduction in the bowhead range relative to the 5500-2500 expansion.

The central argument (Dyke et al., 1996b) in this interpretation of sea ice history is that bowhead whale bones in raised marine deposits represent natural mortality occurring within the region (e.g., channel) of deposition. While some of the remains may derive from live strandings, a possible but unknown form of natural mortality for bowheads, most presumably derive from already dead individuals. Thus, the abundance of bowhead remains can be suggested to be proportional to the population size, the seasonal length of occupation by a population, or both. By corollary, an absence of bowhead remains over thousands of years is taken as evidence that the area was not occupied during the period when the bone-barren shorelines were formed. That is, these barren intervals represent periods during which severe ice conditions prevented bowheads from entering and occupying adjacent waters. Because bowheads are ice-adapted, they follow the annual advance and retreat of the floe edge. Thus, the patterns of fossil bowhead remains allow us to identify expansions and contractions of bowhead habitat and, by extension, major periods of expansion and contractions of summer sea ice cover.

Holocene walrus remains from the CAA display a frequency distribution through time similar to that of the bowhead remains in the same region (Dyke et al., 1999). Evidently both animals responded to a common limiting factor. Because these animals are ecologically dissimilar, the most probable common factor is sea ice condition.

An alternative argument could be made that beaches in which bowhead remains are absent or low in abundance represent major open-water periods, when bowheads abandoned these regions for lack of the ice-edge habitat they require at any time of year. However, as stressed by Dyke et al. (1996b:238), this alternative "requires us to assume that the High Arctic inter-island channels remained free of ice in the winters [during these periods]; i.e., that the whales did not retreat in the autumn to the Davis Strait region, but remained in the Arctic Ocean." Such an interpretation goes absolutely against the known distribution of Holocene bowhead remains: such remains are absent in beaches adjacent to the Arctic Ocean north of Prince Patrick Island (see Dyke et al., 1996b: Figs. 10-19), and there is no known mechanism to explain why whale carcasses adjacent to the Arctic Ocean did not wash ashore, while those in the inter-island channels did so by the thousands.

Accordingly, the present paper builds on the previous bowhead and walrus studies in two ways. First, we compare stranding rates based on all stranded bowhead remains within a restricted number of study areas; that is, we do not limit the comparisons to radiocarbon-dated samples only. The rationale in this case is that, since bowheads float remarkably well at death, they would tend to ground adjacent to, or near, contemporaneous shorelines. The propensity for bowheads to float after death is well illustrated by modern Alaskan Inuit whaling practices; carcasses are often towed after death for 15 to 32 hours (Marquette, 1978) and, in one reported instance, for a full five days (Durham, 1973). Furthermore, the retrieval of 'stinkers' (floating, decomposing carcasses) after several days is a common occurrence (Marquette, 1978). Thus, if the emergence rate for individual raised beach sequences can be determined (from radiocarbon-dated remains of bowheads and other materials, such as mollusc shells and driftwood), then the relative abundance of all bowhead remains, not just those for which radiocarbon dates have been derived, may be used as proxy evidence for major periods of summer sea ice expansion and contraction. This allows for much larger comparative samples within single study localities.

Second, in addition to comparing relative stranded animal abundance through time, we also examine lengthbased mortality patterns associated with these stranded animals. Such patterns can often be a source of information on the causes of mortality and, potentially, population structure.

\section{STUDY AREAS, MATERIALS AND METHODS}

A total of 10 study localities within Navy Board Inlet, Admiralty Inlet, and Prince Regent Inlet are examined in this paper (Fig. 1; note that a much wider region is dealt with in Dyke et al., 1996b). At each locality, we attempted an even inspection of all deposits below the limit of postglacial marine submergence $(70-160 \mathrm{~m})$ along coastal segments of about $5-20 \mathrm{~km}$. Field traverses were closely spaced, and all but one of the study areas was traversed by two teams using different traverse patterns. This method, combined with the fact that bowhead bones are large, only shallowly or partly buried, and marked by vegetation on otherwise barren beach gravels, suggests to us that our inventory of the number of animals represented by the bones is nearly complete. However, at three localities (Lavoie Point, Tikiraq River, and Gallery-localities 1, 4, and 6 in Fig. 1), local topography prevented equal coverage of all beaches below marine limit. In those instances, whale remains outside the area of equal coverage were recorded, but were not considered in determining relative stranding rates. They were, however, included for the purposes of establishing the length-based mortality profiles.

With the exception of the western Prince Regent Inlet sites on Somerset Island, all sites were initially surveyed and sampled by Dyke, who located many crania but essentially limited his sampling to crania with ear bones. Savelle and McCartney (eastern Prince Regent Inlet) and Savelle (western Prince Regent Inlet, Admiralty Inlet, and 


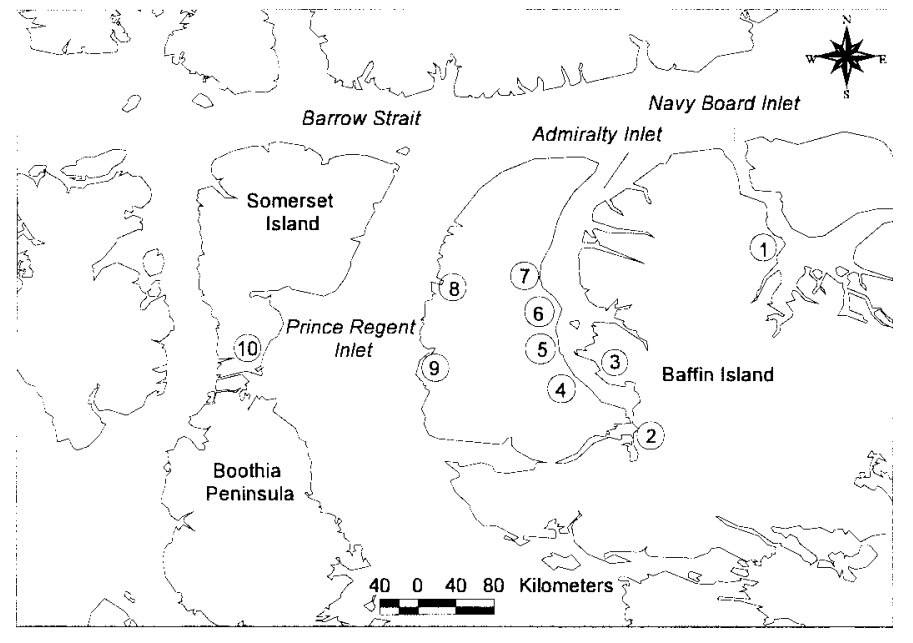

FIG. 1. Eastern Canadian Arctic Archipelago, showing locations of study localities. Navy Board Inlet: 1 = Lavoie Point; Admiralty Inlet: $2=$ Jungerson Bay, 3 = Sunday Bay, $4=$ Tikiraq River, $5=$ Tiriganialaaq River, $6=$ Gallery, 7 = Vista River; Prince Regent Inlet: $8=$ McBean Bay, $9=$ Fitzgerald Bay, $10=$ Hazard Inlet

Navy Board Inlet) relocated Dyke's sampled crania and measured these and any others observed within the study areas in order to derive whale lengths. To avoid sampling any animal more than once, animal counts are based on crania, except in those rare instances where crania were absent, but the context of other bone elements present suggested a high likelihood of separate animals.

The location of each animal was recorded on aerial photographs. Dyke determined elevation above sea level by hand-held altimeter for all specimens he sampled. Savelle and McCartney subsequently employed hand-held altimeters or a transit to determine the elevation of newly recorded specimens, or estimated their elevation relative to Dyke's original elevation data. The latter technique was employed primarily when the new samples were adjacent to Dyke's samples of known elevation, or when the elevation could be determined relative to known lower and higher elevations (typically for specimens 'sandwiched' between two beach ridges of known elevation).

Original bowhead length was determined by applying multiple linear regression models to a series of measurements of historically harvested bowheads. These regressions are based on the animal lengths and the following bone measurements: crania (16 measurements each), mandibles (12 measurements), scapulae (5 measurements), and cervical vertebrae (5 measurements). These models, initially developed by Edward D. Mitchell, then of the Department of Fisheries and Oceans, Canada, are discussed in detail in McCartney (1980). Subsequently, the models were modified with data collected in 1996 from additional skeletal materials from bowheads of known length in Barrow, Alaska. These modified models have been used in the present study and, until published, are available from the senior author. Note that we were careful to avoid sampling any bowhead remains that were associated with prehistoric Thule Inuit whaling sites (ca. 400-
1000 B.P.) in any of the survey areas (see McCartney and Savelle, 1993, and Savelle and McCartney, 1994, for a discussion of these materials). While we cannot be absolutely certain that our stranded sample does not include the occasional Thule-derived carcass that may have drifted away from a Thule settlement area, we consider that such events would be unlikely to alter the overall stranding patterns appreciably, and they could not account for any of the remains above the 1000 B.P. beach, which ranges from less than 1 to $4 \mathrm{~m}$ in this region (Dyke et al., 1996c).

Various materials on beach ridges at the study localities were radiocarbon-dated to derive emergence curves for each site. On the basis of the resulting curves, we determined elevations for the periods during which summer sea ice conditions were favourable to bowhead occupation (hereafter, 'open' conditions) vs. periods when summer sea ice conditions apparently greatly restricted bowhead occupation ('restricted' conditions; see Table 1).

\section{RESULTS}

A total of 769 stranded whales were recorded at the study localities. While we measured all crania, mandibles, scapulae, and cervical vertebrae when encountered, the vast majority of measured bones were crania. Original body length was estimated for 489 animals. Of these estimates, 485 were based on crania and 4 on mandibles.

On the basis of sea ice chronology inferred from bowhead bone abundance, and for the purposes of this paper, we identify two clearly optimal periods of essentially favourable ('open') summer conditions, when the whales extended considerably west of Prince Regent Inlet: 1) from deglaciation (in the CAA beginning about 10000 B.P.) to approximately 8000 B.P., and 2) from 5500 to $3000-$ 2500 B.P.

\section{Relative Whale Abundance}

Whale abundance on the raised beach sequences associated with each of the 'open' and 'restricted' periods for each study locality, overall totals for the three major regions, and the abundance normalized to 1000-year 'stranding rates' are presented in Table 1. Note that the term 'stranding rate' as employed here, based on the total number of individual animals visible on the beach series within the three study regions, is relative only; it does not imply an absolute stranding frequency, nor does it imply that each region can be compared directly to the other two. The stranding rates for each region are in turn compared with the stranding rates represented by the radiocarbondated samples (Table 1 and Figs. 2-4) presented in Dyke et al. (1996b).

In all three regions, the patterns of variation in stranding rates between 'open' and 'restricted' summer sea ice periods are remarkably similar to those derived from radiocarbon dates (Table 1 and Figs. 2-4). That is, the 
TABLE 1. Frequencies of bowhead whales represented on raised beach sequences at the various study locations (numbered as for Fig. 1), and of radiocarbon-dated samples in Dyke et al. (1996b). (For whale abundance, number in parentheses refers to additional specimens recorded outside the area of complete raised beach sequences.)

\begin{tabular}{lcccc}
\hline \hline Location & Level 1 & Level 2 & Level 3 & Level 4 \\
& 2500 B.P. & 2500-5500 B.P. & $5500-8000$ B.P. $8000+$ B.P \\
& to present & & \\
\hline
\end{tabular}

\section{Navy Board Inlet:}

1. Lavoie Point

Beach elevations $(\mathrm{m}) \quad 0-3.5 \quad 3.5-17$

Stranded whales 22(12) 115(3)

Stranded whales/ka $\quad 8.8 \quad 38.3$

C14-dated whales

C14-dated whales/ka

4

1.6

16

5.3

$\begin{array}{cc}17-36 & 36+ \\ 1 & - \\ 0.4 & - \\ 4 & - \\ 1.6 & -\end{array}$

Admiralty Inlet:

2. Jungerson Bay

Beach elevations (m)

Whale abundance

3. Sunday Bay

Beach elevations (m) $\quad 0-10$

Whale abundance

4. Tikiraq River

Beach elevations (m) $\quad 0-10$

Whale abund

5. Tiriganialaaq River

Beach elevations (m)

Whale abundance

6. Gallery

Beach elevations $(\mathrm{m}) \quad 0-6.5$

Whale abundance 48(3)

7. Vista River

Beach elevations (m) $0-4$

Whale abundance 10

$$
\begin{gathered}
11-42 \\
51 \\
10-34 \\
54 \\
10-34 \\
49(1) \\
8-28 \\
24 \\
6.5-27 \\
74 \\
4-17 \\
76
\end{gathered}
$$

Admiralty Inlet Totals:

Whale abundance 146(15)

Whale abundance/ka $\quad 58.4$

C14-dated whales 34

C14-dated whales/ka $\quad 13.6$

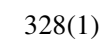

109.3

88

29.3

Prince Regent Inlet:

8. McBean Bay

Beach elevations (m) $0-5.5$

Stranded whales

$0-5.5$

2

$5.5-19$

11

$19-50$

$50+$

9. Fitzgerald Bay

Beach elevations (m) $\quad 0-8$

Stranded whales 4

10. Hazard Inlet

Beach elevations (m) $\quad 0-8.5$

Stranded whales

8

$$
\begin{gathered}
8-27 \\
30 \\
8.5-30 \\
23
\end{gathered}
$$$$
42+
$$

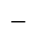

$34+$

$-$

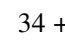

$34+$
1

$28+$

3

$27+$

4

$17+$

10

$\begin{array}{cc}18 & 1 \\ 7.2 & 1.0 \\ 15 & - \\ 6 & -\end{array}$

Prince Regent Inlet Totals:

Whale abundance $\quad 14$

Whale abundance/ka $\quad 5.6$

C14-dated whales

C14-dated whales/ka

14
5
2

64
21.3
24
8

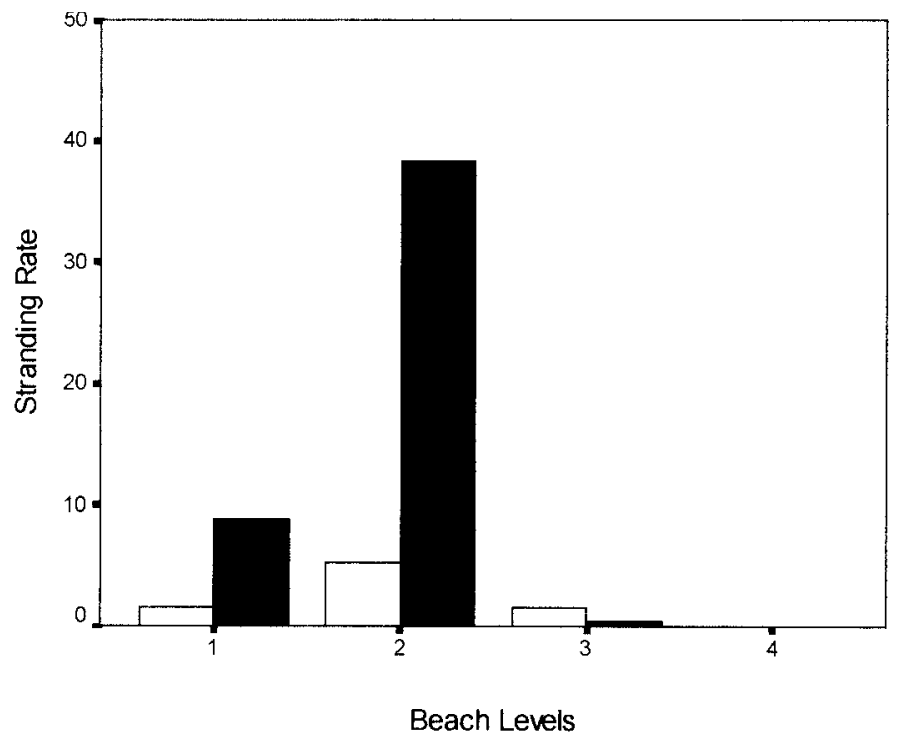

FIG. 2. Stranding rates per 1000 years of radiocarbon-dated samples (white bars) and all beach samples (black bars) according to sea ice environmental period, Navy Board Inlet. Levels: $1=0-2500$ B.P.; $2=2500-5500$ B.P.; $3=5500-8000$ B.P.; $4=8000$ B.P.+.

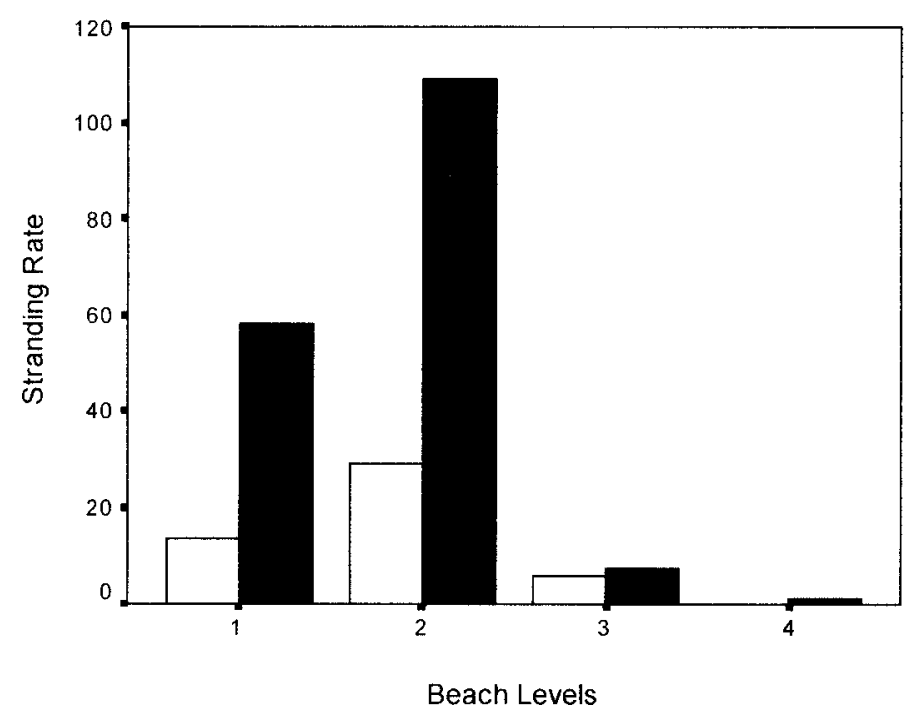

FIG. 3. Stranding rates per 1000 years of radiocarbon-dated samples (white bars) and all beach samples (black bars) according to sea ice environmental period, Admiralty Inlet. Levels: $1=0-2500$ B.P.; $2=2500-5500$ B.P.; $3=5500-8000$ B.P.; $4=8000$ B.P.+.

Admiralty Inlet areas. A partial explanation is that deglaciation of the study sites in these areas occurred mainly between 9000 and 6000 B.P. (Dyke et al., 1996b). Thus, the vast majority of the earliest beaches in these areas postdate the first of the two periods of major bowhead range expansion.

Finally, we conclude on the basis of these sea ice patterns that bowhead remains in the study region predating 10000 B.P. very likely derived from western Arctic bowhead stocks, and that regular intermingling of the eastern and western stocks would have been possible between 10000 B.P. and 8500 B.P. (see reconstructions in Dyke et al., 1996b:345-347).
mid-Holocene peak in radiocarbon-dated bowheads between approximately 2500 and 5500 years B.P. is very prominent in all three regions, as is the almost total exclusion of bowheads between 5500 and 8000 B.P. Furthermore, the early Holocene peak prior to 8000 B.P. is distinct in the Prince Regent Inlet study area. This peak is lacking, on the other hand, in the Navy Board Inlet and 


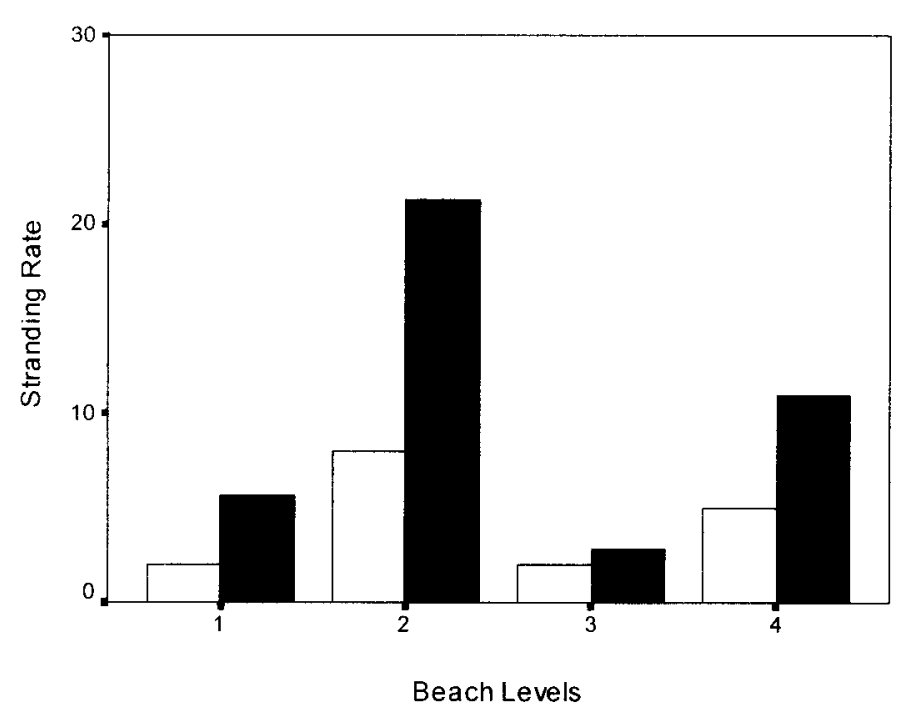

FIG. 4. Stranding rates per 1000 years of radiocarbon-dated samples (white bars) and all beach samples (black bars) according to sea ice environmental period, Prince Regent Inlet. Levels: $1=0-2500$ B.P.; $2=2500-5500$ B.P.; $3=5500-8000$ B.P.; $4=8000$ B.P.+.

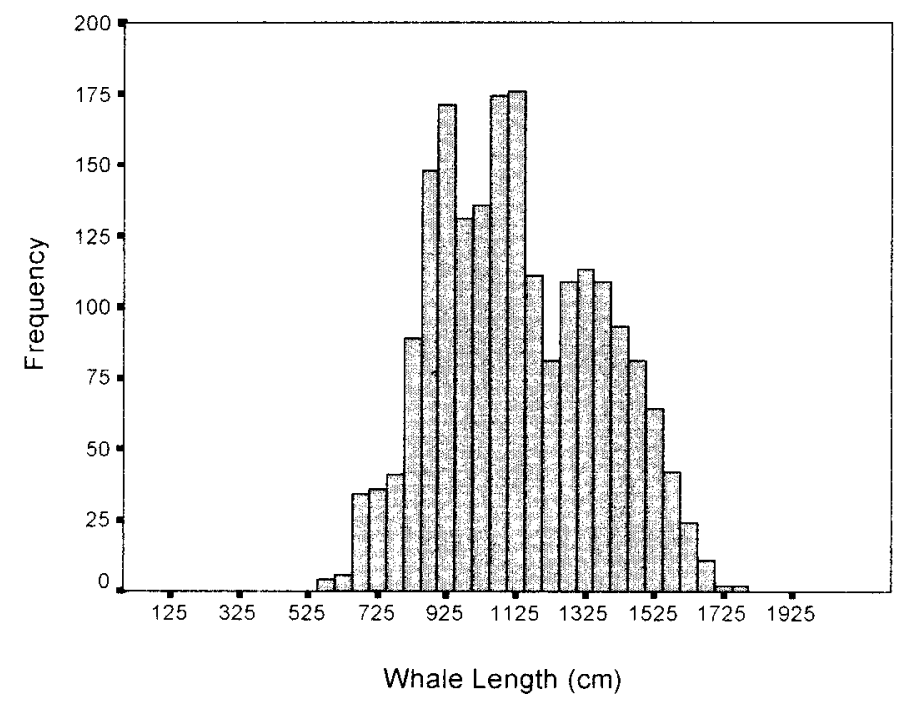

FIG. 5. Estimated length distributions of live bowheads measured photogrammetrically in the Chukchi and Beaufort Seas (1981-86; estimated figures from Koski et al., 1988, $\mathrm{n}=1988$ ).

\section{Bowhead Mortality Profiles}

A mortality profile is usually a frequency distribution of the age at death of a species, or some proxy of that age, for a particular time and place or event. Bowhead mortality profiles herein are based on length assessments, because no reliable method of determining absolute bowhead age from skeletal material exists at present. While no data are available on length frequency distributions for the CAA Davis Strait bowhead stock, from which presumably the vast majority of the whales in the study area derived, comparable data are available for the Bering Sea stock (Koski et al., 1988). Because census data differ considerably from year to year, we used length frequencies from an

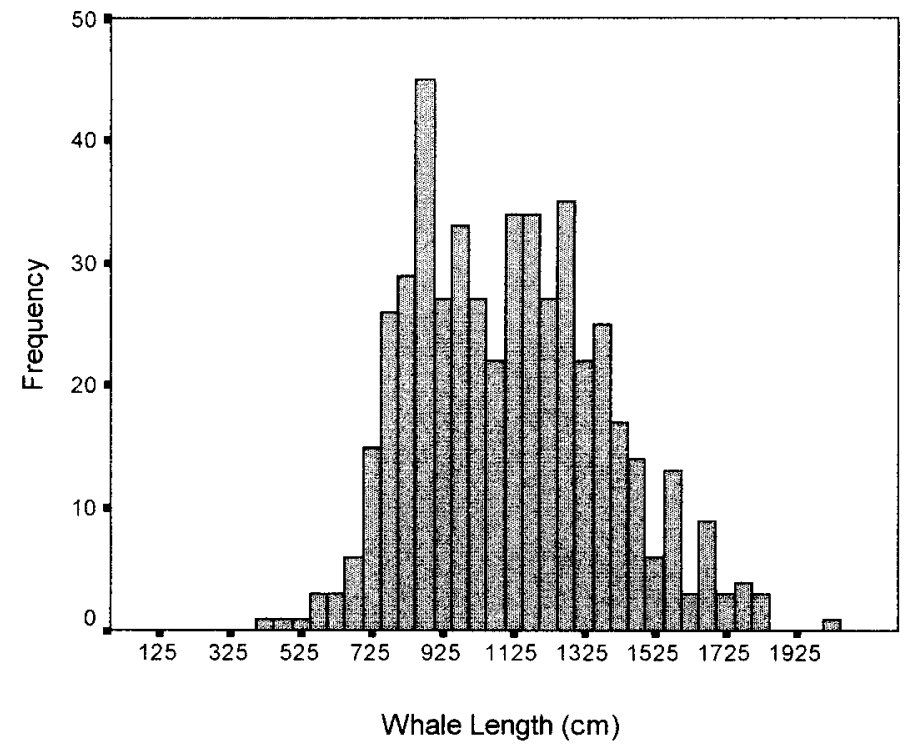

FIG. 6. Estimated length distributions for stranded bowheads in all study localities and all time periods $(n=489)$.

aggregate of censuses taken from 1981 to 1986 (Fig. 5; $\mathrm{n}=1988$ ) for comparison. While this compilation is unlikely to represent a completely unbiased sample, it nevertheless appears to be the most appropriate for general comparisons. Cosens and Blouw (1999) have recently reported on length frequencies of Hudson Bay-Foxe Basin stock bowheads on the basis of censuses conducted in 1996-98 $(\mathrm{n}=82)$. However, given that their sample is much smaller, and that they interpret their data as representative of a sex- and age-segregated substock, we restrict our comparisons to the Bering Sea stock.

Also, note that both Koski et al. (1988) and Cosens and Blouw (1999) determined individual whale length photogrammetrically, whereas we derived our length estimates from regression models based on measurements of landed, Inuit-hunted whales. We are unaware of any study that relates 'live' length to 'landed dead' length, and thus direct comparison between the live and Holocene stranded populations may be appropriate only when comparing overall population structure.

Finally, note that while whale age and whale length can be expected to exhibit an overall correlation, recent studies (e.g., Schell and Saupe, 1993; George et al., 1999) suggest that, especially in the case of whales in the 7-9 $\mathrm{m}$ range, whales of similar length may vary in age by five years or more. Accordingly, we stress whale length categories in our comparisons of population structure.

First, the profile for the total stranded population (Fig. 6) shows a strong resemblance to the Beaufort Sea live population profile. That is, there are few animals less than $7.0-7.5 \mathrm{~m}$ long, one or more strong peaks in the $8.0-13.0 \mathrm{~m}$ range, and a gradual fall-off from about $13.0-13.5 \mathrm{~m}$ to the largest animals in the $17-19 \mathrm{~m}$ range. These similarities in population structure between the aggregate stranded population and the live population suggest that bowhead mortality in the eastern Arctic archipelago during the summer is more 

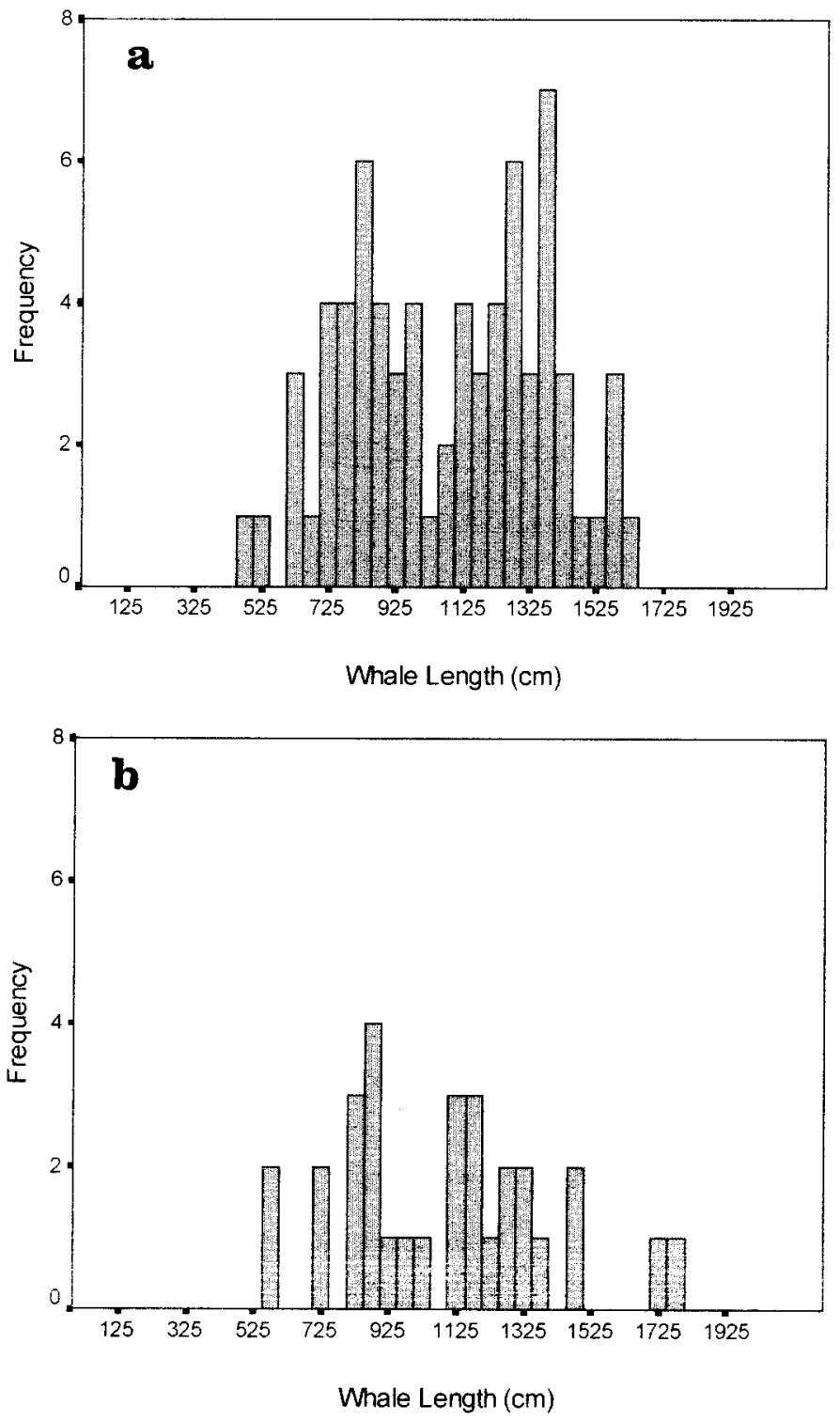

FIG. 7. Estimated length distributions of bowheads in Navy Board Inlet a) during 'open' periods $(n=70)$ and $b)$ during 'restricted' periods $(n=30)$.

likely a result of random processes, such as ice entrapment, than of any processes that are size-selective.

For purposes of further comparison, measured samples from 'open' summer sea ice periods are compared to those from 'restricted' summer sea ice periods for individual regions (Figs. 7-9). Although the samples tend to be limited, especially for the 'restricted' period, there is an overall consistency between the three areas, and this consistency is maintained when 'open' and 'restricted' period samples are aggregated (Fig. 10).

\section{SUMMARY}

The study reported here confirms temporal changes during the Holocene in the relative abundance of stranded bowhead whales in the CAA, as initially reported by Dyke
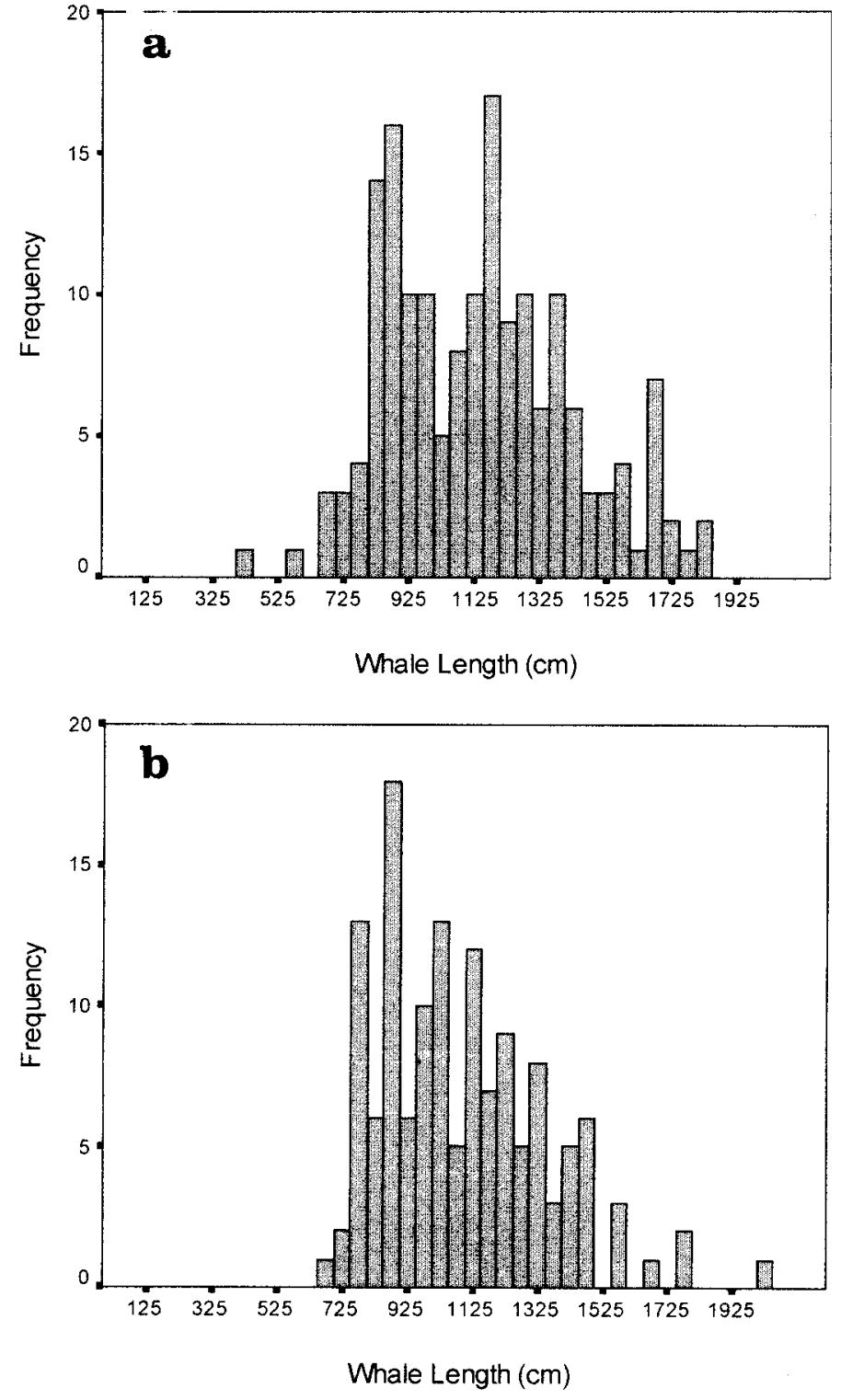

FIG. 8. Estimated length distributions of bowheads in Admiralty Inlet a) during 'open' periods $(n=166)$ and $b)$ during 'restricted' periods $(n=136)$.

and Morris (1990) and Dyke et al. (1996b). Furthermore, it suggests that, if an emergence curve can be independently established for a given locality, changes in relative abundance of stranded bowhead whale remains based on elevation alone offer a potentially robust method of interpreting changes in bowhead whale habitat. In the present study, we examined changes in the form of 'restricted' (as opposed to 'open') summer sea ice conditions.

Regarding the analyses of length-based mortality data, we recognize that the study is in several respects 'coarsegrained.' No doubt additional data and further analyses will refine several of the interpretations presented here. Nevertheless, the resemblance in some detail of the aggregate stranded bowhead mortality profile to the living bowhead stock profiles suggests that the primary causes of bowhead mortality during the summer in the study region do not appear to be size-selective. Mortality is thus more 

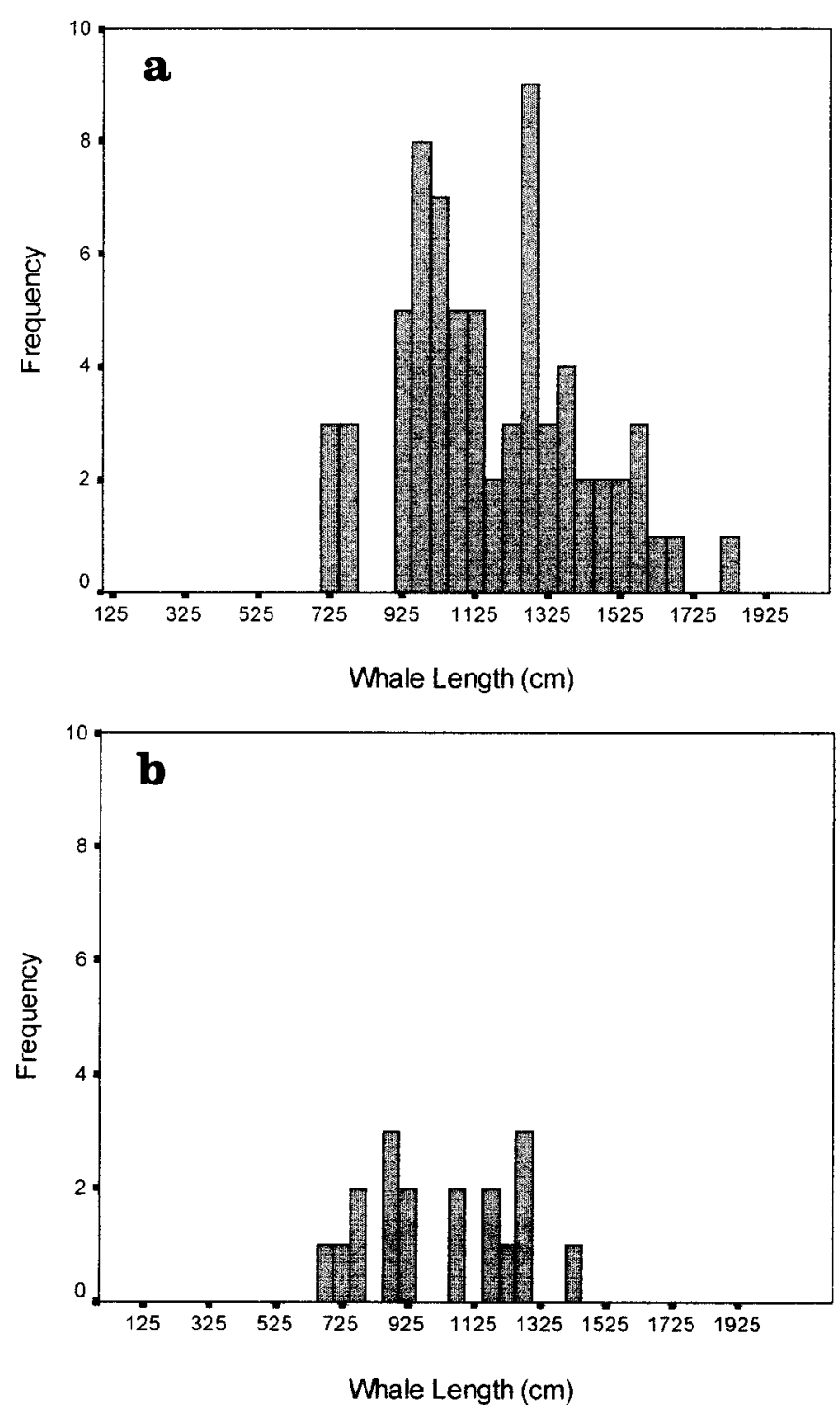

FIG. 9. Estimated length distributions of bowheads in Prince Regent Inlet a) during 'open' periods $(n=69)$ and $b)$ during 'restricted' periods $(n=18)$.

likely due to a random process, such as sea ice entrapment, than to processes such as disease, senescence, and predation, which tend to selectively affect certain age groups. Regarding predation, note that although we have recorded thousands of bowhead bones and tens of beluga, narwhal, and walrus bones in the CAA, we have yet to record one bone of a killer whale, the only known predator of bowhead whales besides humans. Finally, at this rather general level of analysis, there appears to be little, if any, difference in overall population structure between 'open' summer conditions and 'restricted' summer conditions.

\section{ACKNOWLEDGEMENTS}

The fieldwork upon which this study is based was supported over several years by the Polar Continental Shelf Project, the
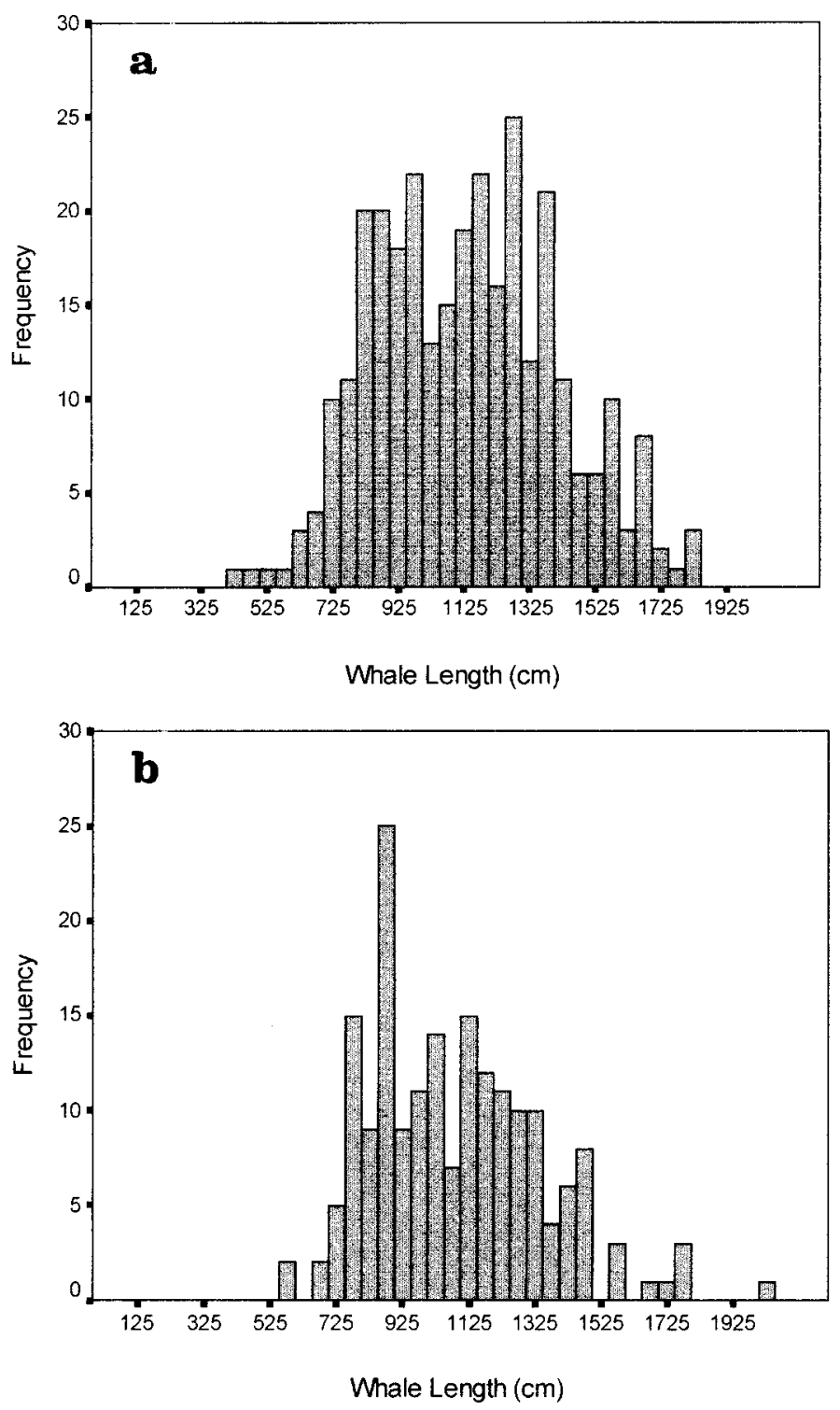

FIG. 10. Estimated length distributions of bowheads in all study localities a) during 'open' periods $(n=305)$ and $b)$ during 'restricted' periods $(n=184)$.

Geological Survey of Canada, the Natural Sciences and Engineering Research Council of Canada, and the Social Sciences and Humanities Research Council of Canada.

A preliminary version of this paper was presented at the 'Currents of Change: Arctic Seas Symposium '98' at Mystic, Connecticut, hosted by the Mystic Aquarium. We thank David J. St. Aubin, Director of Research and Veterinary Services, Mystic Aquarium, for the invitation to participate in the symposium and for the financial assistance that enabled us to attend.

We thank Susan Cosens, Rolph Davis, and a third (anonymous) referee for their very thoughtful and detailed comments, which prompted us to rethink several critical issues. In addition, Susan Cosens kindly provided unpublished copies of her recent bowhead research and gave permission to cite these materials. Finally, we are especially grateful to Mélanie De L'Étoile for her invaluable assistance in the development and application of the revised biometric models. 


\section{REFERENCES}

COSENS, S.E., and BLOUW, A. 1999. Age classes of bowhead whales summering in northern Foxe Basin. Canadian Stock Assessment Secretariat Research Document 99/135. Department of Fisheries and Oceans, Canada.

DURHAM, F.E. 1973. Recent trends in bowhead whaling by Eskimos in the western Arctic with emphasis on utilization. Washington, D.C.: Whale Protection Fund, Center for Environmental Education, Inc.

DYKE, A.S., and MORRIS, T.F. 1990. Postglacial history of the bowhead whale and of driftwood penetration: Implications for paleoclimate, central Canadian Arctic. Geological Survey of Canada, Paper 89-24. 17 p.

DYKE, A.S., MORRIS, T.F., and GREEN, D.E.C. 1991. Postglacial tectonic and sea level history of the central Canadian Arctic. Geological Survey of Canada, Bulletin 397.

DYKE, A.S., DALE, J.E., and McNEELEY, R.N. 1996a. Marine molluscs as indicators of environmental change in glaciated North America and Greenland during the last 18000 years. Géographie physique et Quaternaire 50:125-184.

DYKE, A.S., HOOPER, J., and SAVELLE, J.M. 1996b. A history of sea ice in the Canadian Arctic Archipelago based on postglacial remains of the bowhead whale (Balaena mysticetus). Arctic 49(3):235-255.

DYKE, A.S., McNEELEY, R.N., and HOOPER, J. 1996c. Marine reservoir corrections for bowhead whale radiocarbon age determinations. Canadian Journal of Earth Sciences 33:1628- 1637.

DYKE, A.S., ENGLAND, J., REIMNITZ, E., and JETTE, H. 1997. Changes in driftwood delivery to the Canadian Arctic Archipelago: The hypothesis of postglacial oscillations of the Transpolar Drift. Arctic 50(1):1-16.

DYKE, A.S., HOOPER, J., HARINGTON, C.R., and SAVELLE, J.M. 1999. The Late Wisconsinan and Holocene record of walrus (Odobenus rosmarus) from North America: A review with new data from Arctic and Atlantic Canada. Arctic 52(2): $160-181$.
GEORGE, J.C., BADA, J., ZEH, J., SCOTT, L., BROWN, S.E., O'HARA, T., and SUYDAM, R. 1999. Age and growth estimates of bowhead whales (Balaena mysticetus) via aspartic acid racemization. Canadian Journal of Zoology 77:571-580.

KOSKI, W.R., MILLER, G., and DAVIS, R. 1988. The potential effects of tanker traffic on the bowhead whale in the Beaufort Sea. Indian and Northern Affairs Canada, Environmental Studies 58.

MARQUETTE, W.M. 1978. The 1976 catch of bowhead whales, Balaena mysticetus, by Alaska Eskimos. Marine Fisheries Review 40(11):18-27.

McCARTNEY, A.P. 1980. Study of archaeological whale bones for the reconstruction of Canadian Arctic bowhead whale stocks and whale use by prehistoric Inuit. Final report prepared for the Northern Environmental Protection Branch, Department of Indian and Northern Affairs, Ottawa.

McCARTNEY, A.P., and SAVELLE, J.M. 1993. Bowhead whale bones and Thule Eskimo subsistence-settlement patterns in the central Canadian Arctic. Polar Record 29(168):1-12.

SAVELLE, J.M., and McCARTNEY, A.P. 1994. Thule Inuit bowhead whaling: A biometrical analysis. In: Morrison, D., and Pilon, J.-L., eds. Threads of Arctic prehistory: Papers in honour of William E. Taylor Jr. Canadian Museum of Civilization, Mercury Series, Archaeological Survey of Canada, Paper 149. 281-310.

SCHELL, D.M., and SAUPE, S.M. 1993. Feeding and growth as indicated by stable isotopes. In: Burns, J.J., Montague, J.J., and Cowles, C.J. The bowhead whale. The Society for Marine Mammalogy, Special Publication No. 2. Lawrence, Kansas: Allen Press, Inc. 491-509.

TREMBLAY, L.-B., MYSAK, L.A., and DYKE, A.S. 1997. Evidence from driftwood records for century-to-millennial scale variations of the high latitude atmospheric circulation during the Holocene. Geophysical Research Letters 24:2027-2030. 